Доклад Центра международных исследований МГиМО. - М., 1992. - С. 6-10.

${ }_{11}$ См. фешенко А.С. Явление наднациональности в деятельности международных организаций//Советский ежегодник международного права. 1987. М., 1988. - С. 159-170; Нешатаева Т.Н. Мировой банк и Международный валют ный фонд: правовая идея и реальность//МЖМ. - 1993. - № 2. - С. 87-91.

12 CM. Ilnбaева Е.A. К вопросу о наднациональности межправительственных организаций универсального характера//МЖМП. - 1992. - № 4. - С. 83.

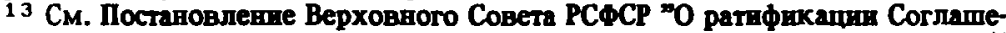
ния о созданпв Содрухества Незавнстмых Государств" от 12 декабря 1991 г.// Ведомости Съезда народных депутатов РСФСР и Верховного Совета РСФСР. 1991. - № 5. - Ст. 17-98; Постановленпе Верховного Совета Республики Беларусы

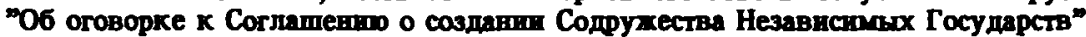
от 16 января 1992 г.//Ведамасці Вярхоунага Савета Рэспублікі Беларусь. - 1992. No 7. - Apr. 135.

14 Например, недавно в Армении появилось простое товарищество как организационная форма предпринимательства, которая, как и английский партнершип, не признается юридическим лицом.

${ }_{15}$ См. Сапдов A.X. Концепция "европейского правового пространства": проблемы и перспективы//МЖМП. - 1992. - № 3. - С. 61.

${ }^{16}$ См. Салдов A.X. Указ. соч. - С. 65.

17 См. Смотров И.А. "ОБщеевропейский дом" и европейское правовое пространство//МЖМП. - 1992. - No 3. - С. 96.

18 Текст оговорок см. Док. ООН A/47/67.

19 Акты Верховного Совета Украины нашли соответствующую оценку и в зарубежной литературе (см. Sheehy A. Op. cit. - P.8).

20 Cодрухество Незавнстиалх Государств... - C.10.

21 Tam zxe. - C. 11.

22 См. Рххевкй: В.А. Указ. соч. - С. 35.

23 Учитывая ситуацию с Молдовой, было введено условие - подписание и ратификация бвзовых документов $к$ моменту принятия Устава. Как теперь ясно, Молдова не является государством-учредителем, зато к их числу относятся Украина и Туркменистан.

24 Текст проекта Договора см. МММП. - 1992. - No 1. - С. 142-149.

\title{
НА ПУТИ К ЕДИНОЙ СИСТЕМЕ ЦЕННОСТЕЙ В РАМКАХ CБCE*
}

Анна К рай кем а й ер **

1. Права человека, демократия и правовое государство как инструменты реформы и безопасности

Стремление народов восточноевропейских стран и бывшего СССР к освобождению от однопартийной системы и к соблюдению прав человека начиная с 1989 года дало значительный импульс ре-

* Перевод с немецкого Н.Б. Шеленковой.

** Научный сотрудник Института исследований проблем мира и политики безоласности (Гамбург). 
формам и революциям. В этом центральное место заняли зашита прав человека, строительство правового государства и укрепление демократии. Парижская Хартия СБСЕ, Маастрихтские соглашения о создании Европейского союза, Заявление о создании СНГ в АлмаАте и другие международные договоры, заключенные за последнее время, а также недавно принятые новые конституции свидетельствуют о признании мировым сообществом единой системы ценностей.

Хотя в пространстве СБСЕ еще есть войны, конфликты и стены, разделяющие народы, признание единой системы ценностей можно рассматривать как предпосылку безопасности и основу для дальнейшего сотрудничества. Чем устойчивее единая система ценностей, тем сильнее будет желание присоединиться к ней. Того, кто заявляет о своем признании совместных ценностей, можно считать сторонником данной концепции. Как следствие - становятся сложными создание образа врага и отказ от сотрудничества из идеологических соображений.

Эашита прав человека, демократия и правовое государство тесно взаимосвязаны с внутренней и внешней безопасностью. Создание единой системы ценностей является предпосылкой для разеешения конфликтов, в основе которых лежат различия интересов, мирным путем. Демократический ненасильственный метод разрешения конфликтов во внутренней политике уменьшает возможность проведения аѓрессивіого внешнеполитического курса ${ }^{1}$. Существование единой системы ценностей и необходимость сотрудничества между государствами могут способствовать снижению напряженности в межгосударственных отношениях. Учреждение демократическими государствами международных организаций позволяет жить "надеждой на будущее" и уменьшает межгосударственную нестабильность ${ }^{2}$.

Права человека могут стать катализатором развития реформ. Во времена антагонизма двух систем требование о воплощении в жизнь универсальных прав человека было лишь инструментом ограниченного реформирования однопартийной системы. Имплементация обязательств в рамках СБСЕ приводила к принятию в зтих странах законов реформаторского характера. Тем самым дальнейшее преследование критиков режима "законным способом" становилось невозможным ${ }^{3}$.

Однако только стремление масс к демократии "снизу" привело к революционизации политических основ и поставило у власти правительства, которые теперь обязаны соблюдать нормы прав человека, демократии и правового государства. В роли хранителя единой системы ценностей сегодня выступает содружество государств - участников СБСЕ. При помощи общих институтов и нового политического 
инструментария оно предпринимает усилия для предотвращения нарушений прав человека, установления диктатуры, авторитаризма и связанных с этим новых антагонизмов.

Исходя из общечеловеческих параметров СБСЕ, поступательное развитие данного процесса может привести к институционализации единой системы ценностей. Проведение трех конференций по человеческому измерению в рамках СБСЕ, создание институтов СБСЕ и внедрение принципов СБСЕ в жизнь, а также становление организационных рамок Совета Европы заложили оснпвы для дальнейших шагов на пути интеграции.

\section{2. Институционаљыые рамки единой системы ценностей: СБСЕ и Совет Европы}

В той мере, в которой возрастает взаимозависимость между Востоком и Западом, усиливается значение институциональных образований на политической арене. Для успешного выполнения своей роли в деле поддержки реформ и укрепления безопасности эти институты должны быть следующими:

- Принципы их организации и деятельности должны отвечать самым высоким требованиям.

- Они должны быть основаны на демократических принципах, а именно: доступны для всех государств-участников СБСЕ, их структура и методы работы должны быть демократичны, они должны создать условия для участия на демократических началах граждан государств-участников в их деятельности.

- Их деятельность должна быть гибкой, то есть они должны учитывать неравномерность развития общественных процессов на всем пространстве СБСЕ и на основе этого должны быть в состоянии предложить всем политическим силам соизмеримые реальные возможности для участия в развитии принципов СБСЕ.

- Их дөятельность должна носить новаторский характер, то есть на основе динамики их развития будут возникать новые формы и принципы межгосударственной торговли, свободные от применения силы.

Таким образом, демократизация деятельности, обеспечение высокого профессионального уровня, дальнейшее развитие инструментов международных отношений, таких как гибкость и открытость, находятся В тесной взаимосвязи. В силу этого сложный процесс сближения между Востоком и Западом должен_ осуществляться постепенно. 
2.1. Приемлемость и измененне принциов СБСЕ. Замечания к правовой квалификачин договоренностей в рамках CBCE

Закономерна постановка вопроса о правовой природе договоренностей в рамках $\mathrm{CБCE}^{4}$. C точки зрения международного права эти документы не носят обязательного характера: здесь речь идет о заявлениях о намерениях. Такой подход в области прав человека часто имел негативную правовую оценку. Именно в данной области особенно важно стремиться к обязательному характеру документов, так как в противном случае такое положение может привести к несоблюдению прав человека. Тем не менее с политической точки зрения такие договоренности в рамках СБСЕ имеют три преимущества:

- Необязательный характер договоренностей может облегчить общее развитие процесса СБСЕ, так как обеспечивает институтам СБСЕ необходимую гибкость.

- К договоренностям в рамках СБСЕ относятся, как правило, как к международным договорам. Они приобрели в какой-то мере обязательный характер, в то время как другие межгосударственные договоренности таким качеством не обладают 5 .

- Договоренности в рамках СБСЕ оказывают стимулирующее воздействие. Они способны регулировать поведение государств наравне с нормами международного права, их можно рассматривать в качестве индикатора возникновения новых международно-правовых стандартов.

В дискуссиях о будущем институционализации СБСЕ выдвигается требование придать договоренностям в рамках СБСЕ международно-правовой обязательный характер. С учетом приведенных выше требований к единой системе ценностей, тем не менее, не следует стремиться к большей степени обязательности данных договоренностей. Договоры, обладающие всеми качествами международных, могут заключаться на уровне организационных структур, непосредственно связанных с процессом СБСЕ.

Процесс СБСЕ носит инновационный характер. Преодоление конфронтации между Востоком и Западом вызвало к жизни процесс институционализации в рамках СБСЕ, который привел к дальнейшему динамичному развитию как формальных, так и внутренне присущих СБСЕ принципов и инструментов 6 . Данное изменение принципов СБСЕ может быть продемонстрировано на основе трех примеров:

От принципа невмешательтва во внутренние дела к требованио такого вмешателства посредством международного контроля 39 нарушением прав человека. Запрет вмешательства во внутренние 
дела (принцип VI Заключительного акта Совещания в Хельсинки) часто использовался в качестве своего рода оговорки: восточноевропейские государства разоблачение нарушений прав человека в этих странах рассматривали как недопустимое вмешательство в их внутренние дела.

Особый характер территориальных конфликтов, конфликтов, связанных с проблемами меньшинств и распадом государств, требует международного вмешательства для защиты "народов и человечества" 7. Это способствует преодолению антагонистической структуры международных отношений. В соотвегствии с этим в международно-правовых и политических дебатах уже в течение продолжительного времени обсуждается проблема права интервенции. Наряду с сохранением в национально-государственных рамках запрета на интервенцию указывается, что на основе хельсинкских принципов следует создать право коллективной интервенции. Дискуссии по вопросу о новом инструментарии международных отношений показы'вают, что применение права интервенции может быть легко урегулировано. Заметим в этой связи, что необходима дифференциация между различными формами вмешательства в различных областях с использованием различных методов ${ }^{8}$.

На уровне СБСЕ с точки зрения общечеловеческих интересов уже сделаны первые, пока еще скромные шаги к формам международного вмешательства во внутренние дела. Создание развернутого Венского механизма (раздел 3.1) - механизм чрезвычайных и превентивных мер 9 - означало, что появилась возможность для международных ненасильственных действий по защите прав человека, демократии и правового государства. На этой основе государства - участники СБСЕ могут поддержать введение в силу механизма, который представляет собой форму ограниченного вмешательства во внутренние дела.

Принши консенсуса. Проблема вмешательства во внутренние дела тесно связана с модификацией принципа консенсуса, который является краеугольным камнем СБСЕ. Несмотря на очевидные недостатки, данный принцип был и остается важнейшей основой для демократического принятия решений ${ }^{10}$. Институционализация процесса СБСЕ ведет к постепенному изменению принципа консенсуса:

- решения в Парламентской ассамблее СБСЕ принимаются большинством голосов (раздел 3.2$)^{11}$;

- в целях зашиты прав человека, демократии и правового государства на встрече министров иностранных дел государств - участников СБСЕ в Праге 30-31 января 1992 г. было принято решение модифицировать принцип консенсуса. В случае, если государство-участник не соблюдает свои обязательства в рамках СБСЕ, остальные госу- 
дарства вправе без его согласия (консенсус минус 1) принять меры, применение которых предусмотрено за пределами территории данного государства (раздел 3.2$)^{12}$;

- принцип консенсуса также не применяется для введения в действие механизма чрезвычайных мер, Венского механизма (дополнен в ходе Московской конференции) или механизма превентивных мер (принят в Хельсинки). Для этого достаточно согласия, соответственно, 12, 9 и 11 государств.

Самоопределение. Народы Центральной и Южной Европы, равно как и территорий СНГ, стремятся к различным формам независимости - от права возвратить прежнее название республики до отделения и образования самостоятельного государства. Между двумя принципами Заключительного акта существует противоречие, а именно: между принципом территориальной целостности и принципом права народов на самоопределение ${ }^{13}$. Стремление к независимости выдвигает на первый план проблему права народов на самоопределение и ставит тем самым под вопрос территориальную целостность. Несмотря на то что СБСЕ предусматривает формы участия в своей деятельности других стран, решение вопроса о таком участии в Совещании Хорватии и Словении, делегации Нагорного Карабаха показало, что СБСЕ было не в состоянии предложить субъектам внутригосударственного уровня подходяџих возможностей для обсуждения их проблем. Критерием участия в СБСЕ является факт международно-правового признания суверенитета государства. В результате препятствием к приему Хорватии и Словении в полноправные члены мирового сообщества было их членство в Югославской Федерации, в то время как государства-правопреемники (в международно-правовом понимании) уже не существующего СССР быстро стали членами Организации Объединенных Наций.

СБСЕ до сих пор не проявило себя в качестве эффективного форума по безопасности и сотрудничеству для конфликтующих сторон на межгосударственном уровне. Они лишены возможности обратиться к какому-либо учреждению для обсуждения проблем в целях избежания конфликтов с применением силы, принимая во внимание существующий и будущий потенциал возникновения конфликтов в результате распада государственных образований в Юго-Восточной Европе и бывшем СССР (например, Российская Федерация, Грузия, Таджикистан). СБСЕ необходимо привести свою деятельность в соответствии с новыми условиями. В этой связи возможно создание механизма превентивных мер и службы Верховного комиссара по делам национальных меньшинств ${ }^{14}$. Тем не менее подобные новые структуры и механизмы позволяют лишь частично решить проблему прав меньшинств (см. раздел 3.3). 


\section{2. Взаммосвязь СБСЕ с Советом Европы}

Исчезновение противостояния двух систем привело к сближению задач СБСЕ и целей интеграционных организаций западноевропейских стран, а тем самым к пересечению областей их деятельности. После периода переориентации институтов (1989-1992 гг.) Хельсинкская встреча СБСЕ 1992 года поставила задачу "интеграции интеграционных образований" 15 , содействия дальнейшему развитию этих институтов в соответствии с критерием "взаимодополняемости". Налицо динамичное взаимодействие между институциональными участниками международных отношений. "Межинституциональные отношения" в форме "диалога между различными институтами" и "межинституциональное разделение труда" приобретают все большее значение ${ }^{16}$.

Институциональное взаимодействие СБСЕ и Совета Европы осуществляется на основе расширения Совета за счет восточноевропейских стран и происходящего в рамках СБСЕ процесса создания новых институтов. Положения по проведению СБСЕ предусматривают участие в нем международных организаций ${ }^{17}$. После проведения в Копенгагене Конференции по человеческому измерению делегация Совета Европы принимает участие в процессе СБСЕ. С этого времени во всех итоговых документах указывается на то, что Совет Европы представляет собой один из институтов для дальнейшей работы над созданием единой системы ценностей на уровне $\operatorname{CБCE}^{18}$.

Сотрудничество СБСЕ и Совета Европы в области прав человека заключает в себе и другие преимущества. Человеческое измерение в рамках СБСЕ можно было бы гибко увязать с соответствуюшими конвенциями Совета Европы. На основе этого страны - участницы СБСЕ смогли бы сделать дальнейшие шаги на пути укрепления международно-правовой обязательности своих решений и тем самым подняться на одну ступеньку выше •в деле создания единой системы человеческих ценностей. В той мере, В которой усиливается процесс институциональной взаимосвязи, происходит дублирование деятельности данных институтов. В области прав человека перед экспертами Совета Европы, СБСЕ и ООН стоит решение задачи, каким образом можно избежать содержательного и институционального дублирования и как следует дальше развивать принципы сотрудничества после завершения Московской конференции по человеческому измерению (10 сентября - 4 октября 1991 г.). Эксперты предупреждают о дублировании стандартов в области прав человека. Например, они указывают на то, что необходимо выяснить, каким образом обязательства в рамках СБСЕ следует согласовывать с деятельностью Совета Европы для достижения гибкости стандартов, с одной стороны, и 
обеспечения их соблюдения - с другой, или это вообще нецелесообразно делать. Было внесено предложение предоставить Совету Европы совещательный статус при СБСЕ и создать согласительную комиссию ${ }^{19}$.

3. Уровень нормативного обеспечения в области прав человека, менњшинств, демократии и правового государства

\section{1. ПРАВА ЧЕЛОВЕКА}

По вопросу о правах и основных свободах человека на встречах в Вене в рамках СБСЕ (1986- 1989 гг.) между Востоком и Западом еще наблюдались очень значительные расхождения. Несмотря на это, участниками было принято обязательство развивать национальное законодательство в соответствии с общеевропейскими стандартами, публиковать документы СБСЕ и сделать тексты законодательных актов общедоступными. Участники подчеркнули целесообразность присоединения к международным и региональным пактам о правах человека.

На уровне СБСЕ, тем не менее, отсутствует процедура установления объективных фактов (fact finding) нарушения прав человека ${ }^{20}$. С созданием Венского механизма (1989 г.) были заложены основы для процедуры международного контроля. В заключительном документе Московской конференции по человеческому измерению было указано на необходимость придать решению задач в области прав человека бо́льшую действенность на основе расширения Венского механизма. Нововведение Московской конференции состоит в возможности посылки комиссии экспертов также и против воли государства, нарушающего права человека. Для достижения этой цели необходимо вступить в противоречие с названными выше принципами СБСЕ: правилом консенсуса и невмешательством во внутренние дела (раздел 2.1).

В Москве все были единодушны в том, что достигнута новая ступень в политике прав человека. На первом месте в деле защиты прав человека находится обязательное в международно-правовом отношении использование механизмов контроля и применения санкций. На уровне СБСЕ Венский механизм предусматривает только две из трех возможных процедур рассмотрения жалоб в случае нарушения прав человека: доклад государства и жалобы государства-участника. Подача жалоб в индивидуальном порядке возможна лишь в Комиссию по правам человека Европейских сообществ. В этой связи следовало бы допустить к подписанию Европейской кон- 
венции по зравам человека (ЕКПЧ) восточноевропейские государства, которые не являются членами ЕС. К третьей Конференции СБСЕ по человеческому измерению немецкая делегация внесла предложение расширить процедуру подачи индивидуальных жалоб также и для государств - участников СБСЕ, не являющихся членами Совета Европы.

Было подчеркнуто, что следут создать такой процедурный механизм для присоединения к ЕКПЧ, который не привел бы к ослаблению принципов данной Конвенции. Совет Европы со своей стороны также ведет поиск приемлемых форм для участия в его деятельности государств, не являющихся членами Совета. Согласно широко распространенному мнению, ЕКПЧ содержит достаточный запас гибкости для конструктивной интеграции государств с различным уровнем развития. Так, в случае, если национальное законодательство еще не в полной мере соответствует положениям Конвенции, за государствами сохраняется право внесения оговорок. С учетом таких предпосылок ЕКПЧ может стать ядром статута Объединенной Европы ${ }^{21}$.

\section{2 ПРАВА МЕНЬШИНСТВ}

Проблемы меньшинств характеризуются многообразием форм их проявления, что заложено в самой сути таких проблем. Поэтому дать всеобъемлющее определение менъшинств представляется достаточно сложным. Все проблемы меньшинств обладают общими чертами. Но, вне зависимости от того, о каком меньшинстве идет речь - религиозном, этническом, языковом или социальном, меньшинства требуют предоставления им специфических прав. Целью современной политики в области меньшинств должно являться создание возможностей для мирного сосуществования людей, представляющих различные группы на внутригосударственном уровне. Государственные границы должны как можно в меньшей степени препятствовать решению этой проблемы. Отметим, что в этой области до сих пор имеет место отсутствие должного законодательного регулирования ${ }^{22}$.

Зашита прав меньшинств возможна, как известно, через индивидуальные и/или коллективные права. В этой связи центральным вопросом является следующий: представляет ли собой защита прав меньшинств зашиту коллективных прав или нет? В Эаключительном документе Конференции СБСЕ в Вене содержатся обязательство защищать права меньшинств и запрет дискриминации. Впервые значительное внимание правам меньшинств и их защите уделил Заключительный документ Конференции в Копенгагене. В нем указывается, 
что "права представителей национальных меньшинств являются частью международно признанных прав человека". Это означает, что ӧпределенная часть индивидуальных прав меньшинств рассматривается как составляющая международных прав. Следовательно, в соответствии с документом коллективных прав при этом не возникает. До сих пор участники СБСЕ не проявили готовности признатъ коллективные права. При этом доказывается, что многообразие прав меньшинств позволяет говорить только о создании единой системы их защиты. В материалах Конференции в Копенгагене указывается, что решение вопроса о национальных меньшинствах возможно только в демократическом правовом государстве. Далее в них подчеркивается, что значительную роль в данном процессе играют неправительственные организации ${ }^{23}$.

Проблемы меньшинств продолжают обсуждаться в рамках СБСЕ. Так, Парижская хартия предусмотрела встречу экспертов по проблемам национальных меньшинств в июне 1991 года в Женеве. Однако, по мнению многих обозревателей, Заключительный документ встречи в Женеве не оправдал ожиданий общественности перед лицом растущей необходимости решения этих проблем. Что касается формулировки защиты прав меньшинств, эксперты пришли к мнению, что из-за их многообразия создание и применение единого метода для всех ситуаций невозможны ${ }^{24}$. В качестве возможных вариантов для обсуждения прав меньшинств эксперты указывают на различные формы участия представителей меньшинств в совещательных органах и органах по принятию решений. Требование рассматривать права меньшинств в качестве коллективных прав признается в Заключительном документе встречи только в самом общем виде. Кроме того, в нем подчеркивается, что права меньшинств являются международным делом и поэтому не могут быть исключительно внутренним делом соответствующего государства.

Вопрос о меньшинствах одновременно заключает в себе несколько аспіектов: с точки зрения прав человека, международного права и политической безопасности. Для поиска путей решения проблем политической безопасности недопустима дифференциация.

Кодификация прав меньшинств представляет собой сложную задачу, так как здесь затрагиваются вопросы суверенитета, автономий и сецессий. Государственные образования критично настроены по отношению к коллективным правам, так как последние в целом благоприятствуют образованию еще одной общности наряду с государством. Это диктовало и сдержанное отношение к данному вопросу В международных документах. С точки зрения политической безопасности важно проводить различие между международно-правовыми последствиями использования права народов на самоопреде- 
ление и использования прав меньшинствами. Использование права народов на самоопределение может привести к образованию автономии, а для защиты прав меньшинств, наоборот, можно использовать преобразования на внутригосударственной основе. В последнем случае в распоряжении находится вся палитра федеральных форм, хотя способы регулирования данного вопроса указывают на все еще недостаточное развитие данной области международного права 25 .

Потребность этнической идентификации могла бы быть удовлетворена через различные формы автономии (культурная автономия, местное и автономное управление, самоуправление, местное правительство). Именно в данной области Совет Европейских сообществ и связанная с ним Конференция обшин и регионов располагают необходимым инструментарием и форумами. В Хельсинкском документе 1992 года в отдельной главе государства - участники СБСЕ заявили о своей поддержке процесса регионального сотрудничества и сотрудничества "без границ".

Начиная с Конференции в Женеве продолжаются дискуссии о внесении в повестку дня вопроса о едином европейском кодексе прав меньшинств, однако до сих пор какие-либо конкретные результаты не достигнуты. Западные государства рассматривают процесс СБСЕ в качестве форума для ослабления конфликтов меньшинств, а принципы и обязательства в рамках СБСЕ - как руководящие направления деятельности в этой области ${ }^{26}$.

На встрече в Хельсинки в 1992 году были сделаны дальнейшие шаги к институционализации: создана служба Верховного комиссара по делам национальных меньшинств. Верховный комиссар входит в состав Бюро по демократическим институтам и правам меньшинств и будет заниматься разрешением конфликтов в данной области. Рамки его деятельности обусловлены недавно созданным превентивным механизмом. В целях предотвращения конфликтов, связанных с проблемами национальных меньшинств, он собирает информацию и дает оценку ситуации, а также проводит инспекции на местах. В случае резкого обострения конфликта он предпринимает попытки организации переговоров между конфликтующими сторонами и делает соответствующие предупреждающие заявления. В соответствии с его мандатом, статус котсрого определяется Комитетом старших должностных лиц, он вправе проводить дальнейшие консультации с конфликтующими сторонами. Эффективность его действий, вместе с тем, не следует переоценивать. Конфликты, в которых он может принимать участие, ограничиваются областью разногласий на межгосударственном уровне. Кроме того, одна из конфликтующих сторон может объявить конфликт террористическим актом другой стороны. В таком конфликте Верховному комиссару запрещается принимать участие ${ }^{27}$. 
С точки зрения защиты прав меньшинств особое значение имеет практика Совета Европейских Сообществ. В этой связи был поднят вопрос о том, следует ли принимать отдельную конвенцию ${ }^{28}$ или модифицировать положения Европейской конвенции по правам человека (ЕКПЧ) ${ }^{29}$. Парламентская Ассамблея Сообществ в своем решении требует принятия дополнительного протокола к ЕКПЧ для защиты прав меньшинств, на основе которого представитель меньшинства мог бы подать жалобу на несоблюдение прав человека в Европейский суд. В качестве вклада в проведение Женевской встречи Совет Европы привел примеры уже апробированных на Западе документов в области защиты прав человека ${ }^{30}$.

\section{3. Мехдународная защита демократии и правового госу- дарства}

Основой единой системы ценностей является закрепление принципов правового государства в национальных конституциях. В то же время конституция не должна препятствовать участию государства в международных договорах. Важными шагами в данном направлении являются имплементация международных обязательств и гармонизация национального правопорядка.

Уже в ходе первой Конференции в рамках СБСЕ по человеческому измерению в Париже (30 мая - 23 июня 1989 г.) было внесено предложение создать единое европейское правовое пространство ${ }^{31}$. Решения Конференции в Копенгагене исходят из в корне изменившейся общественно-политической ситуации в Восточной Европе. Заключительный документ Конференции может служить примером признания участниками принципов демократии и правового государства. В результате установления единых ценностей были заложены новые рамки понятия "суверенитет национального государства"32. С точки зрения значения для международного сотрудничества следует отметить прогрессивный характер Заключительного документа совещания в Копенгагене. Благодаря качественно новому уровню обязательств участников, содержащихся в этом документе, его можно сравнить с новым этапом развития прав человека и международного права.

Третья Конференция СБСЕ по человеческому измерению в Москве подтвердила и углубила положения Копенгагенского документа в области защиты прав человека. На ней было уделено внимание также вопросу международной интервенции для поддержания демократического правопорядка созданию механизма для зашиты демократических институтов. Участники Совещания осудили попыт- 
ки насильственного свержения демократических правительств и подтвердили свою поддержку законным органам демократических государств ${ }^{33}$.

Наряду с договоренностями-о защите демократии и прав человека, после подписания Копенгагенского документа было проведено множество мероприятий, которые должны были способствовать укреплению демократических институтов, особенно в странах, переживающих глубокие реформы. Среди таковых следует отметить:

1. Совещание экспертөв по проблемам демократических институтов (Осюо, 4-15 ноября 1991 г.). На нем было объявлено о проведении совместных мероприятий по содействию и поддержанию демократических институтов в государствах-участниках, включая сравнительное изучение законодательства в области прав человека и основных свобод. Совет Европы и Европейская комиссия "Демократия через закон" были приглашены принять участие в этой работе. В Совет Европы были представлены программы "Demosthenes" и "Dernodroit"; осенью 1992 года в них были внесены изменения в соответствии со специфическими потребностями государств-правопреемников бывшего СССР.

2. В ходе встречи Совета министров иностранных дел государств- участников СБСЕ в Праге (30-31 января 1992 г.) было принято решение о расширенин созданного в ноябре 1991 года в Париже Бю. ро по свободным выборам путем его преобразования в Бюро по де́мократическим институтам и правам человека (БДИПЧ). Это Бюро в настоящее время является главным институтом СБСЕ по человеческому измерению. Наряду со своими первоначальными задачами по сбору информации о выборах и посылке наблюдателей, Бюро будет выступать в качестве клиринговой организации и координационного центра для обмена информацией, оказывать техническое содейст. вие и помогать в деле строительства демократических институтов в Восточной Европе. Планируется создание банка данных, а также проведение семинаров экспертов и осуществление образовательных программ. Кроме того, Бюро ведет реестр экспертов, предлагаемых государствами-участниками для проведения проверок на местах в рамках Венского механизма, а в определенных случаях может также влиять на привлечение тех или иных специалистов. Бюро как один из центральных институтов СБСЕ может координировать мероприятия отдельных государств-участников и способствовать их эффективности. В будущем планируется не просто согласовывать деятельность Бюро и Совета Европы, а стремитьея к тому, чтобы их деятельность носила взаимодополняемый характер.

На встрече в верхах в Хельсинки в июле 1992 года была разработана "Программа координации усилий по поддержке недавно 
принятых государств-участников". В ней идет речь о проведении семинаров и обмене информащией о сущности принципов деятельности СБСЕ. Общее руководство осуществляет БДИПЧ, оно поддерживает, координирует свою работу с государствами-участниками и Советом Европы. В этой программе принимают участие также Центр по предотвращению конфликтов в Вене и Секретариат СБСЕ в Праге.

3. Укрепление демократии означает также и устранение дефицита демократии на уровне общеевропейских институтов ${ }^{34}$. Полномочия Парламентской ассамблеи Совета Европы ограничены декларационной политикой. На уровне СБСЕ планировалось создать парламентский орган, и в апреле 1991 года в Мадриде было принято решение о его создании в составе 254 членов. Планируется, что первоначально предложения по вопросам европейской безопасности и сотрудничеству будут дискутироваться. Намечается проведение ежегодных пятидневных пленарных заседаний с периодической сменой места их проведения. Первое заседание Парламентской ассамблеи СБСЕ состоялось 3-5 июля 1992 г. в Будапеште. Ее решения и рекомендации не имеют обязательного характера, но их принятие происходит на основе большинства голосов. Такой способ принятия решений соответствует происходящему процессу модификации принципа консенсуса.

4. Важное место в процессе СБСЕ после принятия Заключительного документа в Вене принадлежит неправительственным организациям ${ }^{35}$. Неправительственные организации, особенно так называемые "хельсинкские группы" в Восточной Европе, оказали большое воздействие на правительства по вопросу внедрения в практику принципов Заключительного акта Совещания в Хельсинки, особенно тех его принципов, которые касаются защиты прав человека. В Заключительном документе Совещания В Копенгагене подчеркивается "значительная роль неправительственных организаций", а в отдельном приложении к данному акту ставятся вопросы допуска неправительственных организаций и средств массовой информации к деятельности конференций по человеческому измерению. Практика открытого допуска на Конференции по человеческому измерению оправдала себя и была дополнена открытым допуском к документам Конференций и возможностью непосредственного контакта с представителями государств-участников ${ }^{36}$. В документе Московского совещания был сделан еще один шаг в данном направлении: было указано на обязательство государств-участников повысить дееспособность неправительственных организаций также и за пределами соответствующих государств. В ходе встреч в рамках. СБСЕ они получили теперь возможность распространять среди участников заявления и доклады в письменном виде. В рамках усилий по приданию процессу СБСЕ боль- 
шей гласности и демократизации государства-участники будут содействовать распространению информации и созданию возможностей для привлечения неправительственных организаций к участию в деятельности СБСЕ ${ }^{37}$. Со времени встречи на высшем уровне в Хельсинки выделяются уполномоченные лица для поддержания контактов с неправительственными организациями как на национальном уровне, так и на уровне СБСЕ.

$$
\text { * } \text { * }
$$

Человеческое измерение, построенное на принципах СБСЕ, получило сильный импульс развития в связи с изменением политической обстановки в Восточной Европе. В результате проведения ряда совещаний Конференции по человеческому измерению государствами-участниками СБСЕ были заложены основы единой системы ценностей. Это, в свою очередь, могло бы стать нормативным базисом создания и системы всеобщей безопасности.

Основы единой системы ценностей нельзя рассматривать вне практического применения таких норм. Правовые нормы не в состоянии устранить насилие. Их действие по ликвидации конфликтов проявляется только в такой единой системе народов и государств, где в качестве высшего требования признается отказ от применения силы при разрешении конфликтов.

Инструментом предотвращения конфликтов становится многостороннее, основанное на неприменении силы вмешательство во внутренние дела государств с целью защиты прав человека, демократии и правового государства на основе деклараций и направления наблюдательных миссий. Согласие государств с деятельностью таких миссий зависит, кроме всего прочего, от ограничительного характера их полномочий. Целью системы всеобщей безопасности должны стать мягкие средства разрешения конфликтов, приоритетные в сравнении с прямыми формами вмешательства.

В дискуссиях по вопросу об 'эффективности СБСЕ и его инструментария для разрешения конфликтных ситуаций в случае использования силы по спорным вопросам (как, например, в Югославии или Нагорном Карабахе) имел место недифференцированный подход к таким понятиям, как предотвращение и разрешение конфликтов. Возможности СБСЕ в деле предотвращения конфликтных ситуаций были охарактеризованы как неэффективные и не отвечающие поставленным задачам.

Очевидным является тот факт, что СБСЕ не располагает механизмами по устранению эскалации и мирному урегулированию кож ликтов. Однако вместо того, чтобы искать новые методы для урегулирования конфликтов, участники дискуссии на все лады критиковали "непригодные" для предотвращения конфликтов институты СБСЕ и призывали к создани: "сил быстрого реагирования". 
В связи с практической безрезультатностью попыток разрешить югославский конфликт путем международного вмешательства с начала 1992 года на уровне СБСЕ проводится работа над усилением структур и инструментов по преодолению конфликтов. Необходимость данной работы определяется и декларированным в Париже процессом институционализации СБСЕ. При этом планируется осуществить и дальнейшее развитие структур и инструментов безопасности, но не в качестве основных. Анализ Хельсинкского документа 1992 года показывает перемещение центра тяжести от вопросов кооперации и интеграции государств-участников к выработке путей разрешения конфликтов. Если ставить данный вопрос с точки зрения достижения соответствия сознания и поведения государств-участников СБСЕ, меньшинств и отдельных граждан, проживающих на их территории, нормативным основам единой системы ценностей, то укрепление структур и инструментов кооперативной безопасности играет такую же важную роль, как и попытки предотвратить нарушения мира путем коллективных усилий.

1 CM. Bächler G. Gewaltverzicht durch Demokratisierung//Mut zum Frieden. Über die Möglichkeiten einer Friedensentwicklung für das Jahr 2000/Volgt W.R. (Hrsg.) - Darmstadt, 1990. - S. 176-199; Rittberger V. Zur Friedensentwicklung von Demokratien//Aus Politik und Zeitgeschichte B44/87. - 31 Oct. 1987.

2 Senghas D. Die Neugestaltung Europas. Perspektiven und Handlungsgebote// Aus Politik und Zeitgeschichte B18/1991, 26.4.1991. - S. 14-18; Czempiel Emst-Otto. Eine Institution, die Unsicherheit verringert//Frankfurter Allgemeine Zeitung. 21 Aug. 1990.

3 На примере бывшеro CCCP: Zagorsky A., Kashlet Y. The Human Dimension of Politics//International Affaires (Moscow). - 1990. - N 3. - S. 62-73; Zagorsky A. Die menschliche Dimension der KSZE, die Sowjetunion und Ru B land//Hamburger Beiträge zur Friedensforschung und Sicherheitspolitik. - Hamburg, 1992. - Heft 85; Kreikemeyer A. Demokratisierung in der Sowjetunion: Möglichkeiten von Europarat und KSZE//Die "sowjetische Frage": Integration oder Zefall?/Ehrhart HansGeorg (Hrsg.) - Baden-Baden, 1991. - S. 165-182.

4 Дискуссия о правовой природе договоренностей в рамках СБСЕ существует на всем протяжении развития процесса СБСЕ. Существуют различнъе квапфикации ранних и более поздних договоренноетей. В работе над данным вопросом автор руководствуется статьей Schawei $B$ furth Th. Zur Frage der Rechsnatur, Verbindlichkeit und völkerrechtlichen Relevanz der KSZE-Schlu akte//ZaöRV. 1976. - S. 68 ff. Автор приносит особую благодарность г-же Хорст Фишер из университета г. Бохум за высказанные замечания.

5 Государства-участники СБСЕ придерживаются соблюдения своих договоренностей и принимают участие в различных конференциях по проблемам имплементации (см. Bloed A. Institutional Aspects of the Helsinki Process. After the Follow Up Meetings of Vienna//Netherlands International Law Review. - 1989. No. 3. - S. 342-363).

6 CM. Schlager E.B. The Procedural Framework of the CSCE: From the Helsinki Rights law Journal. - 1991. - Vol. 12. - No. 6-7. - P. 221-237; Wetz R. The CSCE's New Look//Radil Free Europe/Radio Liberty. - Research Report, 1992. - Feb. - P. $27-31$.

7 CM. Lutz D.S. Friedensforschung und Völkerrecht. Von einem Recht des Staaten $z u$ einem Recht der Vörker und Menschen//Friedensforschung und Sicherheitspolitik. - 1991. - Sept. Heft 59. - S. 7-12. 


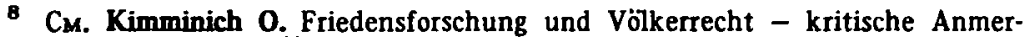
kungen zu Dieter S, Lutz//Lutz, Friedensforschung. - S. 13-18; Bothe $M$. Völkerrecht und Frieden. Brauchen wir ein neues Volkerrecht?//Ibid. - S. 23; Fischer H. Humanitäre Intervention und humanitäre Hilfe/Referat biem Gesprächskreis "Friedensforschung und Vörkerrecht. - Bonn, 1992. - 24. Jan.

9 Mechanismus für Konsultation und Zusammenarbeit in dringlichen Situationen, rerabschiedet auf dem Treffen des KSZE-Au enministerrates in Berlin - 20 June 1991//Europa-Archiv. - 1991. - Folge 14. - S. D 358- D 360; см. также Хешьстикскй документ 1992 года.

10 Тем не менее непоколебимость данного принципа уже была нарушена. Консенсус считается достигнутым уже тогда, когда нет голосов против. Существует также возможность подавать оговорки в письменном виде.

11 CM. Bloed A. Op. cit.; Schlager E. Op. cit.

12 См. Прахский докумевт о дащьейmем развита институтов в струкTYP CECE.

13 В данной связи можно указать на расхождения подобного характера и в Уставе $\mathrm{OOH.}$

14 CM. Weitz R. The CSCE and the Yugoslav Conflict//Radio Free Europe. Radio Liberty Research Report. - 1992. - 31 Jan. - S. 24-26; Lucas M.R. European Security and Minority Rights. - Unveröffentliches Manuskript. - 1991. - Aug.

$15 \mathrm{CM}_{\mathrm{M}}$. Dienstbier J. Erklärung auf dem Au enministerrat der KSZE in Berlin, 19-20 Juni 1991//Europa-Archiv. - 1991. - Nr. 14. - S. D 352; Ibid. S. D335-D360; cM. также Хепстикскй документ 1992 года.

16 CM. Lucas M.R., Kreikemeyer B. (Anns). Der Europarat im gesamteuropäischen Intergrationsproze//Südost-Europa. - 1990. - Nr. 10. - S. 609-626; 0 деятельности Совета Европейских Сообществ недавно появилась работа ка русском языке: Эвтав М.Л. Международные гарантии прав человека. Практика Совета Европы. - М., 1992.

17 CM. Xемстиксквй документ 1992 r.

18 Parliamentary Assembly. Report on the General policy of the Council of Europe. Relations With Countries of Central and-Eastern Europe. - Doc. 6216.-26- Apr. 1990. - S. 3; cM. также Парuxску xaprom.

$19 \mathrm{CM}$. Leuprecht $\mathrm{P}$. Introductory Statement in the ad hoc Committee of Experts to Exchange Views on Standard Setting Activities of the CSCE in the Field of Human Rights (CAHSC)/Council of Europe Churcill Lecture given at Florence, 21 June 1991. - Council of Europe. - Staßbourg, Court (91) 181. - S. 12.

20 CM. Tomuschat Ch. Bewahrung, Stãrkung, Ausgestaltung, zur künftigen Menschenrechtspolitik Deutschlands in der Weltorganisation//S+F, Vierteljahresschrift für Sicheheit und Frieden. - 1992. - No. 1. - S. 5-11.

21 Ibid.

22 CM. Partsch K.J. Bemerkungen zum internationalen Minderheitenschutz// Humanitires Völkerrecht. - 1990. - Heft 3/4 Juli/Dez. - S. 156-159. Проблематичным представляется решение вопроса, когда, например, права человека приходят в противоречие с правами меньшинств, как это может быть в случае ущемления прав женщин, которое основано на религиозных традициях меньшинства. Из выступления Генри Колет в дебатах на парламентском заседании Совета Европейских сообществ 5 февраля 1992 г., цит. по: Haussmann $\mathbf{H}$. Untrennbar mit der Entwicklung der Grundfreiheiten verbunden//Das Parlament. - 28.2./ Mart 1992. Nr. 10-11.

23 См. Документ Копенгагенского совешания Конферевипи по телове qескому измеренио CБCE.

24 Данная формулировка является не только общей фразой с целью завуалировать национальные интересы, но в то же время она представляет собой адекватный ответ на поставленный вопрос. См. Report of the CSCE Meeting of Experts on National Minorities. - Geneva, 19 July 1991//Human Rights Law Journal. 1991. - No. 8-9. - S. 332-334.

$25 \mathrm{CM}$. Ipsen $\mathrm{K}$. Völkerrechtlicher Individualschutz in Konfliktgebieten $/ / \mathrm{S}+\mathrm{F}$ Vierteljahresschrift für Sicherheit und Frieden. - 1991. - Nr. 3. - S. 119-124. 
$26 C_{M}$. United States-European Community statement on peaceful and democratic transformation in the new democracies of Central Europe. - Hague, 1991. - Nov. 9//US Policy Information and Texts. - 1991. Nov. 15. - P. 910.

27 См. Хельсинкский документ 1992 года; Jaberg S. Die Konferenz für Sichetheit und Zusammenarbeit in Europa (KSZE) als Sicherheitssystem, Wandel und Perspektive. - Magisterarbeit an der Universität Mainz. - 1992.

28 Комиссия "демократия через право" (Венецианская комиссия) была учреждена при Совете Сообществ в 1990 году с целью создаті правовые основы для строительства и укрепления демократии. Проявив должную инициативу, она представила предложения но Конвенции о эащите прав меньшинств. Она предложила создать независимый Европейскйй комитет по защите меньшинств в качестве нового органа для рассмотрения зкалоб. Однако это означало бы извесгуое дублирование деятельности существующих институтов.

В ходе международно-правовой дискуссии перед Женевской встречей было выдвинуто предложение передать СБСЕ органы Европейской конвенции по правам человека для правсвой запиты меньшинств, то есть в этом случае ЕКПЧ будет учреждена как орган и Совета Сообществ, и СБСЕ. Преимущество данного предложения по сравнению с предложением Венецианской комиссии заключается в том, что, несмотря на разграничение функций данных институтов, это не приведет к потере прав и будет слособствовать созданию гибкого механизма имплементации. Государства-участники СБСЕ, не входящие в Совет Сообщества, могли бы осуществить имплементацию посредством ассоциирования норм ЕКІІЧ. CA: Breitenmoser St., Richter D. Die Verwirklichung der KSZE-Grundsatze zum Schutze nationaler Minderheiten durch Organleihe bei der EMRK. Entwurf eines Minderheitsschutzprotokolls zur EMRK für die Teilnehmerstaaten der KSZE//Europäische Grundrechtezeitschrift. - 14 June 1991. - Heft 8/9. S. $141-158$.

30 См. Европейская конференция общин и регионов (1951г.), Европейская хартия о местном самоуправлении (1985 r.), Хартия о сотрудничестве без границ (1980г.), Конвенция о межрегиональном сотрудничестве в приграничных областях, которая регулирует участие иностранщев в общественной жнзни (находится в стадия разработки). Кроме того, существует проект Конвенции о защите языков регионов и меньшинств. Разрабатываются также Комвенция об участии иностранных граждан в политической жизни и Хартия о проблемах городов. (Contribution of the Council of Europe to the CSCE meeting of experts on national minorities. - Geneva, 1-19 July 1991//Council of Europe Document. - July 1991.)

31 Предполагалось провести сравнительный анализ законодательства, процессуальных кодексов, судебных систем, исполнительных и судебных институтов, а также согласование дву- и многосторонних инициатив, направленных на развитие единых правовых норм, в целях сближения и гармонизации законодательства (Sticher $\mathrm{Ch}$. Europa als Rechts - und Friedenscerbund - Sicherung der Grundund Menschenrechte - ein Weg europäischer Einigung//Humanitäres Völkerrecht. - Juli/Dez. 1990. - Heft 3/4. - S. 159-168.)

32 Tomushat Ch. Op. cit.

33 См. Документ Московского совепания Ковференция по человеческому нзмеренто СБСЕ.

34 Подобный дефицит демократии, последствия которого еще недостаточно изучены, проявляется в вопросе расширения полномочий не только Парламента ЕЭС, но и других органов подобного рода европейских организаций (например ЗЕС и НATO).

35 Abschlie ₹endes Dokument des Wiener Treffens 1986 der Vertreter der Teilnehmerstaaten đer KSZE. - Wien, 1989. - S. 73.

36 См. Документ Копенгагевското совещания Ковференции по человеческому измеревнио CБCE.

37 Предложение советской делегации на СБСЕ предоставить в будущем неправительственным организациям совещательный статус при ОOH и Совете Европы, а также при СБСЕ до сих пор не вылолнено. 